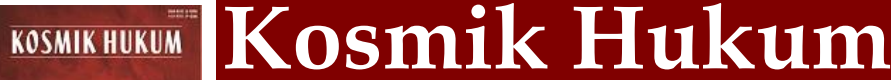

\author{
Fakultas Hukum
}

Universitas Muhammadiyah Purwokerto

Vol. 19 No. 2 (2019)

This work is licensed under a Creative Commons Attribution 4.0 International License (cc-by)

\section{Perlindungan Hukum Terhadap Orang Utan Dari Perdagangan Ilegal}

\author{
Firman Bagus Prasetyo ${ }^{1 凶}$, Rahtami Susanti ${ }^{2}$, Bayu Setiawan ${ }^{3}$ \\ 1,2,3 Fakultas Hukum, Universitas Muhammadiyah Purwokerto \\ E-mail: firmanb1406@gmail.com
}

\begin{abstract}
Illegal trade in protected animals, including orangutans, is still rife in Indonesia, resulting in a decline in population from year to year. This study aims to analyze the legal protection of orangutans from illegal trade, based on Law Number 5 of 1990 concerning Conservation of Living Natural Resources and their Ecosystems and their inhibiting factors. The approach to the problem that will be used in this research is a normative juridical approach. The results of the study show that first, the number of orangutan populations has decreased due to illegal trade and there are several factors that hinder the protection of the orangutan population, such as logging, encroachment and road network expansion. The illegal trade in orangutans is something that must be considered because the punishment imposed on the perpetrators is still too light, with what they are doing. Therefore, the punishment and fines can be heavier so that the perpetrators are deterred. Stop forest hunting by tightening forest guarding and providing education about protected animals to the community. Likewise in protecting animals in the country of Indonesia.
\end{abstract}

Keywords: protection, orangutans, illegal trade

\begin{abstract}
Abstrak
Perdagangan ilegal satwa dilindungi termasuk di dalamnya orang utan masih marak terjadi di Indonesia sehingga mengakibatkan populasinya menurun dari tahun ke tahun. Penelitian ini bertujuan untuk menganalisis tentang perlindungan hukum terhadap orang utan dari perdagangan ilegal berdasarkan UU Nomor 5 Tahun 1990 tentang Konservasi Sumberdaya Alam Hayati dan Ekosistemnya dan faktor-faktor penghambat. Pendekatan masalah yang akan digunakan dalam penelitian ini adalah pendekatan yuridis normatif. Hasil penelitian menunjukan tentang pertama banyaknya populasi orang utan yang terdata menurun karena perdagangan illegal dan terdapat beberapa faktor yang menghambat terhadap perlindungan populasi orang utan seperti penebangan hutan, perambahan dan perluasan jaringan jalan. Perdagangan ilegal orang utan menjadi suatu hal yang harus diperhatikan karena untuk hukuman yang dijatuhkan kepada pelaku masih terlalu ringan, dengan apa yang merka perbuat. Maka dari itu untuk hukuman dan dendanya bisa lebih di beratkan supaya pelaku jera. Memberhentikan pemburuan dihutan dengan cara memperketat penjagaan hutan dan memberikan edukasi mengenai satwa yang dilindungi kepada masyarakat. Begitu juga dalam melindungi satwa yang ada di negara Indonesia.
\end{abstract}

Kata kunci : perlindungan,orang utan, perdagangan ilegal

Copyright@2019KosmikHukum. All rights reserved.

\section{Pendahuluan}

Pembangunan sumber daya alam hayati dan ekosistemnya pada hakikatnya adalah bagian integral dari pembangunan nasional yang berkelanjutan sebagai pengamalan Pancasila. Untuk menjaga agar pemanfaatan sumber daya alam hayati dapat berlangsung dengan cara sebaik-baiknya, maka diperlukan langkah-langkah konservasi sehingga sumber daya alam hayati dan ekosistemnya selalu terpelihara dan mampu mewujudkan keseimbangan serta melekat dengan pembangunan itu sendiri. ${ }^{1}$ Undang-Undang No. 5 Tahun 1990 tentang Konservasi Sumber Daya Alam Hayati dan Ekosistemnya dijelaskan satwa adalah semua jenis sumber daya alam hewani yang hidup di darat,dan atau di air dan atau di udara sedangkan

${ }^{1}$ Supriadi; Hukum Kehutanan dan Hukum Perkebunan di Indonesia; PT Sinar Grafika; Jakarta; hal 544. 2011 
Kosmik Hukum Vol. 19 No. 2 (2019): 151-159

E-ISSN: 2655-9242 | P-ISSN: 1411-9781

DOI: $10.30595 /$ kosmikhukum.v19i2.8628

satwa liar adalah semua binatang yang hidup di darat,dan atau di air dan atau di udara yang masih mempunyai sifat-sifat liar, baik yang hidup bebas atau yang dipelihara oleh manusia. Jenis-jenis satwa yang hidup diberbagai tempat sangat bervariasi baik dalam hal ukuran maupun warna ${ }^{2}$

Perdagangan ilegal, secara komersial dapat meraup keuntungan yang sangat besar, sehingga menjadikan motivasi bagi pemburu liar untuk berlomba-lomba mencari satwa yang dilindungi. Peredaran ilegal satwa liar yang dilindungi adalah kegiatan yang merupakan ancaman terhadap kelangsungan hidup satwa begitu juga dengan orang utan yang merupakan satwa dilindungi. Orang utan merupakan satwa endemik, yang hanya bisa ditemukan di Kalimantan, Sumatra, dan sebagian Malaysia. Hewan ini memiliki tiga subspesies, yakni Pongo pygmaeus, Pongo abelii, dan Pongo tapanuliensis. ${ }^{3}$

Berdasarkan hasil PHVA (Population and Habitat Viability Analysis) orang utan, diperkirakan terdapat 71.820 individu orang utan yang tersisa di Pulau Sumatera dan Borneo (Kalimantan, Sabah dan Serawak) di habitat seluas 17.460.600 hektar. Populasi tersebut tersebar ke dalam 52 metapopulasi dan hanya 38\% di antaranya diprediksi akan lestari (viable) dalam 100-500 tahun ke depan. Sejak dikaji pada PHVA 2004 yang lalu, kajian tentang populasi dan distribusi orang utan Sumatera (Pongo abelii) yang dilakukan semakin berkembang dan lebih rinci. Popoulasi dan distribusi orang utan Sumatera dari yang semula diprediksi ada 6.667 individu, tersebar di habitat seluas 703.100 hektar pada batas ketinggian di bawah $800 \mathrm{~m} \mathrm{dpl}$, saat ini populasinya diperkirakan ada 14.470 individu dan menempati habitat seluas 2.155.692 hektar. Orang utan Sumatera dapat dijumpai di habitat sampai dengan ketinggian 1.500 mdpl, tersebar di 10 metapopulasi. Orang utan borneo (Pongo pygmaeus) diperkirakan terdapat 57.350 individu, menempati habitat seluas 16.013 .600 hektar yang tersebar di 42 kantong populasi. Sekitar 18 individu di antaranya diprediksi akan lestari dalam waktu 100-500 tahun ke depan. Kondisi ini memperbaharui fakta 10 tahun lalu yang menyebutkan bahwa populasi orang utan Borneo diprediksi sekitar 54.817 individu pada habitat seluas 8.195 .000 hektar . Dari hasil analisis ini terlihat adanya kecenderungan penurunan populasi dari 0.45-0.76 individu/Km2 menjadi 0.13-0.47 individu/Km2. Berdasarkan kajian kelangsungan hidup populasi (Population Viability Analysis/PVA), angka minimum populasi orang utan Kalimantan yang dapat bertahan dalam suatu habitat adalah 200 individu dengan kemungkinan kepunahan kurang dari 1\% dalam 100 tahun, kurang dari 10\% dalam kurun waktu 500 tahun. Memasuki 2019, populasi orang utan di Pulau Kalimantan semakin berkurang. Jika sebelumnya status populasinya genting, kini keberadaan orang utan di Kalimantan memasuki tahap kritis. Dulu Kalimantan masih aman, populasinya antara 35.00055.000. Tapi setelah survei naik lagi keparahannya, sekarang sama dengan Sumatera, kritis. Status kritis atau critically endangered ini ditetapkan oleh International Union for Conservation of Nature. Sumatera telah lebih dulu menyandang status ini. Penyebab jatuhnya populasi orang utan, kata Rondang, masih masalah klasik. Hidup orang utan terancam sebab habitatnya dirampas untuk kepentingan manusia. Pada tahun 2017 saja, laju deforestasi masih di kisaran 97.000 hektar. $^{4}$

Tabel 1. Tabel Perkiraan populasi orangutan

\begin{tabular}{ccc}
\hline No & Lokasi & Perkiraan Jumlah \\
\hline 1. & Sumatera (Pongo Abelii ) & 13.710 \\
2. & Tapanuli ( Pongo Tapanuliensis ) & 760 \\
3. & Kalimantan (Pongo Pygmaeus ) & 5730 \\
\hline
\end{tabular}

\footnotetext{
${ }^{2}$ Lembaga Pemuliaan Lingkungan HIdup dan Sumber Daya Alam Majelis Ulama Indonesia. “Pelestarian Satwa Langka untuk Keseimbangan Ekosistem". Penuntut social fatwa MUI No.4 tahun 2014 . hal 30

${ }^{3}$ Leden Marpaung. Tindak Pidana Terhadap Hutan, Hasil Hutan dan satwa. Penerbit Erlangga, 1995 Jakarta.,.hlm. 55.

${ }^{4}$ Forum Orang Utan Indonesia ( Forina ) Orangutan Population and Habitat Viability Assessment (PHVA) 2016 Analisis Kelayakan Populasi dan Habitat Orangutan di Indonesia
} 
Populasi orang utan yang terdata dari tahun ke tahun angkanya menurun drastis, penurunan ini dipicu oleh perdagangan ilegal, seperti contoh kasus dua ekor anakan orang utan yang disita dari hasil perdagangan ilegal satwa liar di Medan. Balai Gakkum Kementerian Lingkungan Hidup dan Kehutanan (Gakkum KLHK) Wilayah Sumatera Seksi Wilayah I menetapkan seorang warga berinisial IG (38) sebagai tersangka kasus perdagangan orang utan (31/1/2020). Pada saat penggerebekan di temukan dua individu anakan orang utan yang masih berusia 2 tahun (jantan), dan 1 tahun (betina). Dari hasil penyelidikan sementara diketahui bahwa IG melakukan pemburuan orang utan di hutan untuk tujuan di jual kembali. Atas perbuatannya tersebut IG diputus bersalah melanggar Pasal 21 (2) Undang-Undang No. 5 Tahun 1990 tentang Konservasi Sumber Daya Alam Hayati dan Ekosistemnya dan dijatuhi pidana 2 tahun 9 bulan dan denda 100 juta. Orang utan merupakan satwa dilindungi yang diatur dalam Peraturan Menteri Lingkungan Hidup dan Kehutanan No P.106 Tahun 2018 tentang Perubahan Kedua Atas Perubahan Peraturan Menteri Lingkungan Hidup dan kehutanan Nomor P.20/MENLHK/SETJEN/KUM 1/6/2018 tentang jenis tumbuhan dan satwa yang dilindungi dan Undang-Undang No. 5 Tahun 1990 tentang Konservasi Sumber Daya Alam Hayati dan Ekosistemnya. ${ }^{5}$

\section{Rumusan Masalah}

Rumusan masalah dalam penelitian ini pertama bagaimana perlindungan terhadap orang utan dari perdagangan ilegal dan kedua faktor-faktor apa yang menghambat perlindungan orang utan sebagai satwa dilindungi dari perdagangan ilegal?

\section{Metodologi Penelitian}

Penelitian ini menggunakan metode studi kepustakaan (library research) untuk mendapatkan bahan pustaka atau data sekunder sebagai bahan dasar untuk diteliti dengan cara mengadakan penelusuran terhadap peraturan-peraturan dan literatur-literatur yang berkaitan dengan permasalahan yang diteliti.

\section{Hasil Dan Pembahasan}

1. Perlindungan hukum terhadap orang utan dari perdagangan ilegal

Konservasi sumber daya alam hati adalah pengelolaan sumber daya alam hayati yang pemanfaatanya dilakukan secara bijaksana untuk menjamin kesinambungan persediannya dengan tetap memelihara dan meningkatkan kualitas keanekaragaman dan nilainya. ${ }^{6}$ Sumber daya alam hayati dan ekosistemnya merupakan bagian terpenting dari sumber daya alam yang terdiri dari alam hewani, alam nabati ataupun berupa fenomena alam, baik secara masingmasing maupun bersama-sama mempunyai fungsi dan manfaat sebagai unsur pembentuk lingkungan hidup, yang kehadirannya tidak dapat diganti. Untuk mengatur hal tersebut maka diterbitkanlah kebijakan yaitu Undang-Undang No 5 tahun 1990 tentang Konservasi Sumber Daya Alam Hayati dan Ekosistemnya. ${ }^{7}$

Strategi konservasi sumber daya alam hayati dan ekosistemnya dilakukan melalui beberapa pendekatan yaitu:

\footnotetext{
5 Garda Animalia ( Pembela Satwa Liar ) Gerakan Masyarakat Sipil Untuk Keadilan Bagi Satwa Liar https://gardaanimalia.com/tersangka-perdagangan-orangutan-ditetapkan-terancam-hukuman-5-tahun-penjara/ ${ }^{6}$ Rachmad K.Dwi Susilo. Sosiologi Lingkungan Hidup. Jambi 2018

7 Asriadi Arief. Implementasi dan Evaluasi Terhadap Undang-Undang Nomor 5 Tahun 1990 Tentang Konservasi Sumber Daya Alam Hayati Beserta Ekosistemnya. (Rabu, 16 Maret 2016 ) diakses dari : http://blogueau.blogspot.com/2016/03/implementasi-dan-evaluasi-terhadap.html?m=1 pada 19 April 2020
} 
Kosmik Hukum Vol. 19 No. 2 (2019): 151-159

E-ISSN: 2655-9242 | P-ISSN: 1411-9781

DOI: 10.30595/kosmikhukum.v19i2.8628

1. Perlindungan system penyangga kehidupan

2. Pengawetan keanekaragaman jenis tumbuhan dan satwa serta ekosistemnya.

3. Kawasan Suaka Alam.

Kawasan suaka alam merupakan kawasan dengan ciri khas tertentu baik didarat maupun diperairan yang mempunyai fungsi pokok sebagai kawasan pengawetan keanekaragaman jenis tumbuhan dan satwa beserta ekosistemnya yang berfungsi sebagai wilayah system penyangga kehidupan.

4. Pengawetan jenis tumbuhan satwa.

Menurut Pasal 20 tumbuhan dan satwa digolongkan dalam jenis :

a) tumbuhan dan satwa yang tidak dilindungi,

b) tumbuhan dan satwa yang dilindungi.

5. Kawasan Pelestarian Alam

Kawasan ini mempunyai fungsi untuk perlindungan system penyangga kehidupan, pengawetan keanekaragaman jenis tumbuhan dan satwa serta pemanfaatan secara lestari sumber daya alam hayati dan ekosistemnya (Pasal 30).

6. Pemanfaatan jenis tumbuhan satwa liar

Pemanfaatan jenis tumbuhan dan satwa liar dapat dilaksanakan dalam bentuk pegkajian, penelitian, dan pengembangan, penangkaran, perburuan, perdagangan, peragaan, pertukaran, budidaya tanaman obatobatan, pemeliharaan untuk kesenangan.

7. Pengawetan jenis tumbuhan satwa.

Peran serta mastarakyat dalam konservasi sumber daya alam hayati dan ekosistemnya diarahkan dan digerakkan oleh Pemerintah melalui berbagai kegiatan yang berdaya guna dan berhasil guna (Pasal 37). ${ }^{8}$

Populasi orang utan menghadapi ancaman kepunahan, dalam beberapa dekade terakhir. Penurunan populasi orang utan diperkirakan mencapai $30-50 \%$ pertahun. Penyebab utama penurunan populasi orang utan adalah kerusakan habitat akibat illegal logging, kebakaran hutan dan perburuan liar. Upaya konservasi untuk menyelamatkan populasi orang utan dari kepunahan dilakukan dengan berbagai cara, antara lain menetapkan orang utan sebagai satwa yang dilindungi. Satwa lindung adalah semua binatang yang hidup di darat dan atau di air dan atau di udara yang masih mempunyai sifat-sifat liar, baik yang hidup bebas maupun yang dipelihara oleh manusia, hal itu tercantum dalam Undang - undang No. 5 Tahun 1990 tentang Konservasi Sumber Daya Alam Hayati dan Ekosistemnya. Upaya lain yang dilakukan adalah melakukan rehabilitasi terhadap orang utan yang telah disita dari masyarakat yang memelihara secara ilegal, perdagangan ilegal dan penyelundupan. Rehabilitasi orang utan tersebut dilakukan dengan melepasliarkan kembali (release) ke habitat alaminya..$^{9}$

Pasal 21 Ayat 2 Undang- Undang No 5 tahun 1990 tentang Konservasi Sumber Daya Alam Hayati dan ekosistemnya yang berbunyi "Setiap orang melarang untuk:

a. Menangkap, melukai, membunuh, menyimpan, memelihara, mengangkut, memperniagakan satwa yang dilindungi dalam keadaan hidup;

b. Simpan, memeliki, merawat mengangkut, dan memperniagakan satwa satwa dalam keadaan mati;

c. Mengeluarkan satwa yang dilindungi dari tempat di indonesia ketempat di dalam atau diluar indonesia;

\footnotetext{
${ }^{8}$ Sembiring N Suhaedi, Tentang kajian hukum dan kebijakan pengelolaan kawasan konservasi di Indonesia menuju pengembangan desentralisasi dan pengkajian peran serta masyarakat. ICEL. Jakarta 1990

${ }^{9}$ Hadi Sofyan, Perilaku Dan Jelajah Harian Orangutan Sumatera (Pongo Abelli Lesson, 1827) Rehabilitan Di Kawasan Cagar Alam Hutan Pinus Jantho, Aceh Besar. Jurnal Ilmu Kehutanan Vol. VII No.1 Januari-Maret 2017
} 
d. Memperniagakan, menyimpan atau memiliki kulit, tubuh atau bagianbagian lain satwa yang dilindungi atau benda barang yang di buat dari bagian-bagian ini atau dikeluarkannya dari tempat di indonesia ketempat lain di dalam atau diluar indonesia;

e. Mengambil, merusak, memusnahkan, memperniagakan, menyimpan atau memiliki telur dan / atau sarang satwa yang dilindungi.

Pasal 40 ayat (2) dan (4) memuat sanksi pidana untuk pelanggaran atas Pasal 21 (1), (2) yang berbunyi :

(2)Barang siapa dengan sengaja melakukan pelanggaran terhadap ketentuan sebagaimana dimksud dalam Pasal 21 ayat (1) dan ayat (2) serta Pasal 33 ayat (3) di pidana dengan pidana penjara paling lama 5 (lima) tahun dan denda paling banyak Rp. 100.000.000,00 (seratus juta rupiah).

(4)Barang siapa karena kelaliannya melakukan pelanggaran terhadap ketentuan sebagiman dimaksud dalam Pasal 21 ayat (1) dan ayat (2) serta Pasal 33 ayat (3) dipidana dengan pidana kurungan paling lama 1 (satu) tahun dan denda paling banyak Rp. 50.000.000,00 (lima puluh juta rupiah).

Penangkapan satwa yang dilindungi hanya diperbolehkan untuk keperluan penelitian, ilmu pengetahuan, dan/atau menyelamatkan jenis tumbuhan atau satwa yang bersangkutan, selain itu, batasan dari pelestarian satwa yang dapat pula yang dilakukan karena hal oleh salah satu sebab satwa yang dilindungi dapat membahayakan mahluk hidup manusia. Membahayakan disini berarti tidak hanya untuk jiwa manusia juga menimbulkan gangguan atau keresahan atau ketentraman hidup manusia, atau kerugian materi seperti rusaknya lahan atau tanaman hasil pertanian." 10 . Hal tersebut sesuai dengan Pasal 30 ayat 2 Kepmenhut Nomor 277/Kpts-II/2003 Tahun 2003 tentang Tata Usaha Pengambilan atau Penangkapan dan Peredaran Tumbuhan dan Satwa Liar, yaitu :

a) Hanya dapat dilakukan untuk tujuan pengkajian, penelitian dan pengembangan dan pengembangbiakan;

b) Permohonan diajukan oleh pemohon kepada Menteri Kehutananm yang memuat diantaranya informasi mengenai jenis, jumlah, jenis kelamin, umur atau ukuran dan wilayah pengambilan serta dilengkapi dengan rencana kerja atau proposal dengan tembusan kepada Dirjen dan otoritas keilmuan;

c) Dalam hal permohonan tidak dilengkapi dengan rekomendasi dari otoritas keilmuan, maka Dirjen meminta rekomendadi dari otoritas keilmuan bahwa pengambilan atau penangkapan yang dimohonkan tidak akan merusak populasi dihabitat alam.

d) Berdasarkan permohonan dan penilaian kelengkapan sebagaimana dimaksud dalam huruf $b$ dan huruf $c$, menteri dapat menyetujui atau menolak menerbitkan izin berdasarkan saran dari direktur jenderal dan rekomendasi dari otoritas keilmuan bahwa pengambilan atau penangkapan yang dimohonkan tidak akan merusak populasi di habitat alam. ${ }^{11}$

Prosedur perizinan untuk memelihara hewan yang dilindungi yang diterbitkan oleh BKSDA ( Badan Konservasi Sumber Daya Alam) yang persyaratannya :

1. Proposal izin penangkaran;

${ }_{10}$ Pasal 21 Ayat 2 Undang-Undang No 5 tahun 1990 tentang Konservasi Sumber Daya Alam Hayati dan Ekosistem.

11 Keputusan Menteri Kehutanan Nomor 227/Kpts-II/2003 Tahun 2003 tentang Tata Usaha Pengambilan atau Penangkapan Perdaran Tumbuhan dan Satwa Liar 
Kosmik Hukum Vol. 19 No. 2 (2019): 151-159

E-ISSN: 2655-9242 | P-ISSN: 1411-9781

DOI: $10.30595 /$ kosmikhukum.v19i2.8628

2. Foto copy KTP untuk individu/perseorangan dan akta notaris badan usaha;

3. Surat keterangan Bebas Gangguan Usaha dari Kecamatan setempat;

4. Bukti tertulis asal usul indukan;

5. BAP persiapan tekhnis;

6. Dan surat Rekomendasi dari kepala BKSDA setempat. ${ }^{12}$

Organisasi yang mendukung perlindungan dan pelestarian keanekaragaman hayati yaitu World Wide Fund (WWF). WWF adalah Non-Government Organization yang peduli terhadap kelestarian keanekaragaman hayati yang mana WWF juga memiliki lebih dari 5 juta pendukung di seluruh dunia ,dan WWF adalah organisasi yang memiliki konservasi independen terbesar yang juga beroperasi lebih dari 100 negara dan WWF juga memiliki Funding yang berasal dari sumber Internasional seperti DFID, USAID dan pemerintah juga membutuhkan dukungan dari WWF karena sangat terfokus pada visi flora fauna yang memilki dana yang memadai sedangkan pemerintah sangat minim dengan anggaran dan WWF melakukan advokasi pada kebijakan hukn dan dalam penegakan hukum dalam upaya pelestariaan $^{13}$

Penanggulangan perdagangan ilegal orang utan yang dilakukan oleh Kementerian Lingkungan Hidup dan Kehutanan melakukan langkah-langkah serta upaya dalam menghentikan perburuan dan perdagangan ilegal orang utan. Kementerian Lingkungan Hidup dan Kehutanan memperkuat jaringan kerja yang melibatkan masyarakat, LSM, akademisi dan orgainasasi lain nya untuk lebih proaktif mendukung penanganan perdagangan ilegal orang utan. Kementerian Lingkungan Hidup dan Kehutanan memiliki beberapa cara dalam menanggulangi dan menekan angka perdagangan illegal orang utan dengan cara Advokasi peraturan dan perundang-undangan, Peningkatan sarana dan prasarana, Keterlibatan aktif masyarakat dan pihak-pihak lain. Advokasi peraturan dan perundangan yang dilakukan Kementrian Lingkungan Hidup dan Kehutanan bersama pihak terkait tengah melakukan revisi terhadap UU No.5 Tahun 1990 tentang Konservasi Sumber daya Alam Hayati dan Ekosistemnya. Peningkatan Sarana dan Prasana dalam meningkatkan sarana prasarana serta anggaran bagi aparat hukum dalam meningkatkan penegakkan hukum perdagangan illegal orang utan di Indonesia dilakukan oleh Kementerian Lingkungan Hidup dan Kehutanan guna terjalinnya kerjasama yang ideal dan meminimalisir terjadinya kesalahan komunikasi antar penegak hukum dalam menanggulangi perdagangan illegal orang utan. ${ }^{14}$

Rangkaian kegiatan analisis kelangsungan hidup populasi dan habitat (Population and Habitat Viability Analysis/PHVA) orang utan sumatera (Pongo abelii) dan orang utan kalimantan (Pongo pygmaeus), dimulai sejak 2015, dan ditutup dengan lokakarya pada bulan Mei 2016 di Bogor, Jawa Barat, Indonesia. Setelah melalui beberapa proses penyutingan, dokumen hasil analisis ini diterbitkan pada 2019. Kemudian, hasil dari PHVA Orangutan 2016 digunakan sebagai acuan utama dalam penyusunan Strategi dan Rencana Aksi Konservasi Orangutan (SRAK) 2019-2029, sebagai pengganti SRAK 2007-2017 yang telah berakhir. Rangkaian kegiatan analisis ini terlaksana atas kerjasama Direktorat Jenderal Konservasi Sumber Daya Alam dan Ekosistem Kementerian Lingkungan Hidup dan Kehutanan Republik Indonesia dengan Forum Orang utan Indonesia (FORINA), Orangutan Foundation-United Kingdom, IUCN SSC Primate Specialist Group, IUCN SSC Conservation Breeding Specialist Group, juga didukung oleh lembaga-lembaga dan para praktisi-pemerhati konservasi orangutan. ${ }^{15}$

\footnotetext{
12 Muhammad Iqbal. . Kepemilikan dan Penjualan Satwa Langka Tanpa Izin di Indonesia. Kalimantan. 2014

13 Sarahswati Ramadhanty. Peran World Wide Fund dalam Menanggulangi Perdagangan Ilegal Harimau Sumatera di Riau. Universitas Dipenogoro. 2018

14 Marpaung Leden. Tindak Pidana Penyelundupan Masalah dan Pencegahan. Jakarta: gramedia Pustaka Utama. 1991

15 Direktorat Jenderal Konservasi Sumber Daya Alam dan Ekosistem Kementerian Lingkungan Hidup dan Kehutanan Republik Indonesia dengan Forum Orangutan Indonesia (FORINA) 2007-2017
} 


\section{Faktor-faktor yang menghambat perlindungan orang utan sebagai satwa dilindungi dari perdagangan iegal}

Bisnis perdagangan satwa liar termasuk bisnis yang bernilai miliaran rupiah bahkan diperkirakan mencapai \$19 miliar per tahun. Bisnis ini mempunyai daya tarik yang besar karena menjanjikan keuntungan yang besar tetapi resiko yang dihadapi kecil. Hukuman bagi pelaku perdagangan ilegal orang utan, ternyata tidak memberikan efek jera karena pada umumnya hukuman yang diberikan masih terlalu rendah. Selain ringannya hukuman untuk pelaku, terdapat beberapa faktor lain yang turut serta menghambat perlindungan orang utan dari perdagangan ilegal yaitu:

\section{a) Penebangan Hutan}

Penebangan hutan mengakibatkan penurunan kualitas habitat satwa liar, baik jangka pendek maupun jangka panjang. Kegiatan eksploitasi kayu secara resmi ataupun ilegal dapat merusak habitat orang utan antara 50 \% sampai kerusakan total. Dampaknya komunitas orang utan terpecah menjadi unit-unit yang lebih kecil dan tidak mampu bertahan hidup. Selain itu, kerusakan habitat sangat mempengaruhi kemampuan orangutan untuk melakukan reproduksi, yang akhirnya akan menyebabkan populasinya di alam semakin menurun.

b) Perambahan

Pertumbuhan penduduk telah mendorong perkembangan infra struktur sehingga lahan menjadi langka, dan pada akhirnya merambah hutan negara, yang di mata sebagian masyarakat merupakan tanah terbuka, baik hutan yang berfungsi konservasi, lindung, maupun produksi. Peningkatan jumlah penduduk yang relatif cepat di sekitar kawasan konservasi, seperti cagar alam atau suaka margasatwa memberikan hal negatif terhdap kelestarian orang utan.

c) Perluasan Jaringan Jalan

Pembukaan dan perluasan jalan merupakan salah satu alternatif untuk membuka akses masyarakat lokal ke daerah lain atau kota namun tidak dipungkiri hal tersebut sering menjadi ancaman bagi kelestarian kawasan tersebut, termasuk di sekitar CADS (Cagar Alam Dolok Sipirok). ${ }^{16}$

\section{Penutup}

1. Kesimpulan

Hak politik penyandang disabilitas termasuk disabilitas mental merupakan salah satu komponen dari Hak Asasi Manusia yang harus dipenuhi dalam negara demokrasi. Hak tersebut penting untuk dihormati, dilindungi, dan dipenuhi demi terwujudnya keadilan penghapusan diskriminasi politik terhadap penyandang disabilitas mental. Penyandang disabilitas mental sejatinya adalah orang yang terganggu fungsi pikir, emosi, dan perilakunya yang berdasarkan keterangan pakar psikiatri disabilitas mental adalah kondisi episodik atau tidak permanen. Meskipun penderita mengalami disabilitas sebagian fungsi mental, mereka tetap bisa hidup normal dan mampu menentukan yang terbaik. Keberadaan hak asasi manusia dalam konsepsi negara hukum yang menganut paham demokrasi di Indonesia pada akhirnya menjadi suatu hal yang paling mendasar yang harus dihormati, dilindungi dan dipenuhi tanpa mengesampingkan golongan tertentu. Secara yuridis penyandang disabilitas mental berhak

16 Wanda Kuswanda. ANCAMAN TERHADAP POPULASI ORANGUTAN SUMATERA (Pongo abelii Lesson)*) (Threats to The Population of Sumatran Orangutans/Pongo abelii Lesson) . jurnal penelitian hukum dan konservasi alam Vol IV No.4 : 409-417,2007 
Kosmik Hukum Vol. 19 No. 2 (2019): 151-159

E-ISSN: 2655-9242 | P-ISSN: 1411-9781

DOI: $10.30595 /$ kosmikhukum.v19i2.8628

untuk memilih dan dipilih dan ikut serta dalam pemilu berdasarkan Putusan MK 135/PUUXIII/2015, Pasal 13 Poin a Undang-Undang Nomor 8 Tahun 2016 Tentang Penyandang Disabilitas, Pasal 5 Undang-Undang Nomor 7 Tahun 2017 tentang pemilu. Kemudian upaya KPU melalui Surat Edaran Nomor 1401/PL.02.1-SD/01/KPU/ CI/2018 meminta Komisi Pemilihan Umum di semua provinsi dan kabupaten/kota untuk mendata warga negara Indonesia penyandang disabilitas grahita atau gangguan jiwa/mental dan dimasukkan dalam daftar pemilih tetap (DPT) Pemilihan Umum (Pemilu) 2019.

Sebagaimana ketentuan dalam Putusan Mahkamah Konsitusi 135/PUU-XIII/2015, bahwa orang sakit jiwa atau orang gila itu tidak sepenuhnya dia akan sakit jiwa atau gila sampai dia meninggal. Dengan bantuan medis yang tepat, orang yang sakit jiwa atau gila itu bisa saja sudah mengalami kesembuhan dan menjadi orang normal kembali. Yaitu dibuktikan dengan surat keterangan dokter bahwa yang bersangkutan tidak sedang sakit atau tidak disabilitas mental lagi. Untuk mewujudkan tujuan hukum yaitu keadilan, maka penyandang disabilitas mental dapat dicatatkan terlebih dahulu dalam daftar pemilih. Ketika waktu pencoblosan mereka dapat hadir untuk menggunakan hak pilih dengan pendamping atau pengampunya serta membawa keterangan dokter bahwa penyandang disabilitas mental tersebut telah sembuh atau sudah sehat jiwa dan ingatannya. Upaya yang dilakukan Komisi Pemilihan Umum dalam menjamin pemenuhan hak penyandang disabilitas mental sudah tepat melalui Surat Edaran Nomor 1401/PL.02.1-SD/01/KPU/ CI/2018. Namun mengenai hak-hak politik yang dimiliki penyandang disabilitas selama ini belum tersampaikan kepada para penyandang disabilitas termasuk disabilitas mental.

\section{Saran}

Berdasarkan pada kesimpulan diatas maka dapat penulis berikan saran meliputi : Pertama, Negara memfasilitasi sarana dan prasarana serta memberikan ruang yang seluasluasnya dalam mewujudkan hak politik seluruh warga negara termasuk penyandang disabilitas mental. Kedua, Perlu adanya sosialisasi kepada masyarakat, khususnya keluarga dari penyandang disabilitas mental agar dapat memberikan perhatian berupa pendampingan terhadap anggota keluarga yang menderita disabilitas mental.

\section{Daftar Pustaka}

Arief,Asriadi. 2016. Implementasi dan Evaluasi Terhadap Undang-Undang Nomor 5 Tahun 1990 Tentang Konservasi Sumber Daya Alam Hayati Beserta Ekosistemnya.

Arif Firmansyah Herliyanto. 2019. Sanksi Pidana Terkait Perdagangan Ilegal Satwa Liar yang Dilindungi.Jurist-Diction: Vol. 2 No. 3, Mei 2019

Direktorat Jenderal Perlindungan Hutan Dan Konservasi Alam Departemen Kehutanan 2007 Strategi Dan Rencana Aksi Konservasi Orangutan Indonesia 2007- 2017

Fathi Hanif, S.H., M.H. 2015. Upaya Perlindungan Satwa Liar Indonesia Melalui Instrumen Hukum dan Perundang-Undangan. JURNAL HUKUM LINGKUNGAN VOL. 2 ISSUE 2, DESEMBER 2015

Forum Orang Utan Indonesia ( Forina ) Orangutan Population and Habitat Viability Assessment (PHVA) 2016 Analisis Kelayakan Populasi dan Habitat Orangutan di Indonesia

Garda Animalia ( Pembela Satwa Liar ) Gerakan Masyarakat Sipil Untuk Keadilan Bagi Satwa Liar (Selasa 17 Maret 2020 ) diakses dari : https://gardaanimalia.com/tersangka-perdaganganorangutan-ditetapkan-terancam-hukuman-5-tahun-penjara

Kuswanda, Wanda 2007. ANCAMAN TERHADAP POPULASI ORANGUTAN SUMATERA (Pongo Abelii Lesson)*) (Threats To The Population Of Sumatran Orangutans/Pongo Abelii Lesson) . jurnal penelitian hukum dan konservasi alam Vol IV No.4 : 409-417 
Leden, Marpaung. 1991. Tindak Pidana Penyelundupan Masalah dan Pencegahan. Jakarta: gramedia Pustaka Utama.

Lembaga Pemuliaan Lingkungan HIdup dan Sumber Daya Alam Majelis Ulama Indonesia. "Pelestarian Satwa Langka untuk Keseimbangan Ekosistem". Penuntut social fatwa MUI No.4 tahun 2014

Marpaung ,Leden. 1995. Tindak Pidana Terhadap Hutan, Hasil Hutan dan satwa. Penerbit Erlangga Jakarta

Ramadhanty, Sarahswati.2018. Peran World Wide Fund dalam Menanggulangi Perdagangan Ilegal Harimau Sumatera di Riau. Universitas Dipenogoro. Journal of International Relations, Volume 4, Nomor 2, 2018, hal. 155-164

Seokanto, Soerjono. 1983. Faktor-Faktor Yang Mempengaruhi Penegakan Hukum.Jakarta: Rajawali Pers.

Sofyan Hadi. 2017. Perilaku Dan Jelajah Harian Orangutan Sumatera (Pongo Abelli Lesson, 1827) Rehabilitan Di Kawasan Cagar Alam Hutan Pinus Jantho, Aceh Besar. Jurnal Ilmu Kehutanan Vol. VII No.1 Januari-Maret 2017

Suhaedi, Sembiring N. 1990 . Tentang kajian hukum dan kebijakan pengelolaan kawasan konservasi di Indonesia menuju pengembangan desentralisasi dan pengkajian peran serta masyarakat. ICEL. Jakarta 1990

Supriadi. 2011. Hukum Kehutanan dan Hukum Perkebunan di Indonesia; PT Sinar Grafika; Jakarta;

Suteki dan Taufan, Galang. 2018. Metode Penelitian Hukum (Filsafat, Teori, dan Praktik). Depok: Rajawali

Wildanu S Guntur. 2019 . KAJIAN KRIMINOLOGI PERDAGANGAN ILEGAL SATWA LIAR. Recidive Volume 8 No. 2 Mei - Agustus 2019

Zain, Alam Setia. 1997. Hukum Lingkungan Konservasi Hutan dan Segi-Segi Pidana (Rineka Cipta) 